\title{
Civil Engineering Procedure
}

Eighth edition 
Downloaded by [] on [26/04/23]. Copyright @ ICE Publishing, all rights reserved. 


\section{Civil Engineering Procedure}

Eighth edition

\section{Institution of Civil Engineers}


Published by ICE Publishing, One Great George Street, Westminster, London SW1P 3AA.

Full details of ICE Publishing representatives and distributors can be found at:

www.icebookshop.com/bookshop_contact.asp

Fifth edition published 1996

Sixth edition published 2009

Seventh edition published 2016

Other titles by ICE Publishing:

Initial Professional Development, Second edition

HM Steels. ISBN 978-0-7277-6098-2

www.icebookshop.com

A catalogue record for this book is available from the British Library

ISBN 978-0-7277-6427-0

(c) Thomas Telford Limited 2021

ICE Publishing is a division of Thomas Telford Ltd, a wholly owned subsidiary of the Institution of Civil Engineers (ICE).

All rights, including translation, reserved. Except as permitted by the Copyright, Designs and Patents Act 1988, no part of this publication may be reproduced, stored in a retrieval system or transmitted in any form or by any means, electronic, mechanical, photocopying or otherwise, without the prior written permission of the Publisher, ICE Publishing, One Great George Street, Westminster, London SW1P 3AA.

This book is published on the understanding that the author is solely responsible for the statements made and opinions expressed in it and that its publication does not necessarily imply that such statements and/or opinions are or reflect the views or opinions of the publishers. While every effort has been made to ensure that the statements made and the opinions expressed in this publication provide a safe and accurate guide, no liability or responsibility can be accepted in this respect by the author or publishers.

While every reasonable effort has been undertaken by the author and the publisher to acknowledge copyright on material reproduced, if there has been an oversight please contact the publisher and we will endeavour to correct this upon a reprint.

Cover photo: New (2017) rail bridge over the river Irwell, for the Ordsall Chord rail link project, Salford, England, UK. lowefoto/Alamy Stock Photo

Commissioning Editor: Michael Fenton

Development Editor: Melanie Bell

Production Editor: Madhubanti Bhattacharyya

Marketing Specialist: April Nagy

Typeset by Academic + Technical, Bristol Index created by Madelon Nanninga-Franssen

Printed and bound in Great Britain by Bell and Bain, Glasgow

Downloaded by [] on [26/04/23]. Copyright @ ICE Publishing, all rights reserved. 


\section{Contents}

Foreword

Preface to the eighth edition

Drafting panel and acknowledgements

01

Civil engineering projects

02

Concept and promotion of a civil engineering project

03

Feasibility

04

Project strategy

05

Design

06

Civil engineering construction contracts

07

Planning and control of construction

08

Construction management organisation

09 Inspection, testing, commissioning and handover

10

Operation, maintenance and asset management

11

Building information modelling (BIM)

Glossary

Appendices

A Conditions of contract for civil engineering

B Further reading

C Useful addresses and websites

Index 
Downloaded by [] on [26/04/23]. Copyright @ ICE Publishing, all rights reserved. 
In the canon of classic civil engineering textbooks, there are few that enjoy the privilege of multiple editions. That this textbook has now reached its eighth is a huge tribute to the successive drafting committees since that first edition in 1963. Granted, there were 26 editions of Rankine's Manual of Civil Engineering to humble that claim, but that began its journey in 1862, not 1963.

I have kept the second edition of Civil Engineering Procedure since my undergraduate years at Edinburgh - a (large) pocket-sized handbook that was a welcome relief from theory and gave a glimpse of real-world practice to naive aspiring engineers. Its full value was to be realised later when it helped navigate the early encounters with contract documents and construction management.

The eighth edition would be scarcely recognisable to the engineers of the 1960s and 1970s. In upholding the principles of that first edition - "to describe the established organisation and methods of working in the industry' - the successive editions of this guide have reflected the evolving status of what is considered to be 'established' civil engineering procedure.

Intervals between successive editions have steadily reduced since 1996 and the pace of changing practice is unlikely to slow down, the natural consequence of a vibrant profession. This latest edition brings the series firmly up to date.

The need for clear, straightforward explanations of project and contract management principles and practice is all the more important as options for commercial and project delivery models become increasingly sophisticated. But underneath what may appear to be a highly complex set of contractual conditions and incentives lie the fundamental principles described in this book. The engineer of today can rely on these principles for the knowledge and understanding to nurture deeper and stronger professional expertise, just as engineers benefitted 
from the earlier editions in, arguably, a simpler landscape.

The need for skilled professionals in this field will not diminish. When I returned to the University of Edinburgh (Rankine's alma mater) after a career in major programmes, I was pleased to seed the idea of a new MSc course in Leading Major Programmes. This developed in far more capable hands into a suite of multidisciplinary modules covering the very broad range of skills and personal qualities required for the successful delivery of the most complex megaprojects in any sector - engineering, IT, healthcare, government enterprises, etc. This book will be required reading to introduce civil engineering procedures to students of all backgrounds.

Gordon Masterton OBE DL FREng FRSE PPICE FIStructE

Chair of Future Infrastructure, The University of Edinburgh

President, Institution of Civil Engineers, 2005-2006 


\section{Preface to the eighth edition}

The Institution of Civil Engineers first published Civil Engineering Procedure in 1963 for the price of 5s. 0d. (10s. 0d. for non-members). The report coalesced two post-war national development reports by the Council of ICE - one was entitled The Organization of Civil Engineering Work and the other The Contract System in Civil Engineering and aimed to 'give students and young engineers a broad and simple description of the established organisation and methods of working in the industry.' Two members of the original drafting committee were later to become Presidents of the Institution of Civil Engineers: Ralph Freeman (Freeman, Fox and Partners - designers of the Severn and Humber Bridges) and Roger Le Geyt Hetherington (Binnie and Partners).

The preface to the first edition further states, 'The report sets out the relative responsibilities and duties of the promoter, the engineer and the contractor, who are the three main parties concerned in the conception, design and execution of civil engineering work, and the parts played by each of them. It is hoped that this information, and the manner of its presentation, will prove useful both to the junior engineer whose aim should be to become familiar with this subject, and to the senior in the instruction of his pupils.'

The eighth edition of this text, published during a period of significant political and economic uncertainty in the UK, coincides with the UK's departure from the European Union on 31 January 2020 by virtue of the European Union (Withdrawal) Act 2018 and the European Union (Withdrawal Agreement) Act 2020.

Despite progress in developing strategic planning for infrastructure investment through bodies such as the National Infrastructure Commission, data from the IHS Markit/CIPS Purchasing Managers' Index published in the Financial Times on 4 November 2019 shows that "construction remained weak, despite rising to 44.2 in October from 43.3 in 
September. Any reading below 50 indicates a majority of companies reported falling output.'

The University of Manchester Department of Mechanical, Aerospace and Civil Engineering remain the privileged custodians of this important text, drawing on support and guidance from a group of experienced practitioners involved with the delivery of some of the UK's most challenging projects and programmes. We inherited the text from the Management Panel of the Institution of Civil Engineers and we are grateful to them for providing us with a solid foundation to work from.

In this edition, we have incorporated the latest updates to the New Engineering Contract (NEC4). The University of Manchester and the NEC have a strong connection in Martin Barnes CBE, who read for his doctorate at the former University of Manchester Institute for Science and Technology (UMIST) under the supervision of Stephen Wearne FICE. His work demonstrated the value of integrating the project control areas of time, cost and quality, known today as the 'iron triangle'. His research at Manchester led him to pioneer the New Engineering Contract, which is known globally for its unique, project management centric approach to project execution.

Richard Kirkham

Manchester, April 2020 


\section{Drafting panel}

\section{Chair}

Richard Kirkham (The University of Manchester)

\section{Panel Members}

Ian Besford (Mott MacDonald)

Martin Cook (DQM Solutions Ltd)

Brian Duguid (Mott MacDonald)

Terri Harrington (Highways England)

Anna Evans (Lendlease)

Stewart Hartley (Lendlease)

Matthew Kirkham (CBRE)

David Ling (The University of Manchester)

Richard Ploszek (Infrastructure and Projects Authority)

Jack Rostron (J Rostron Solicitors, Chair of the Residential Property Tribunal Wales and member of the First-tier Tribunal (Property Chamber), England)

Peter Schwanethal (Alarch Ltd)

Jon Svikis (Mott MacDonald)

\section{Acknowledgements The chair is grateful for the advice and guidance (The University of Edinburgh) and Dr William Craig (Reader in Geotechnics, The University of Manchester (retired)).}

